\title{
Production efficiency of Poland farm-scale biogas plants: A case study
}

\author{
Krzysztof Pilarski ${ }^{1}$, and Agnieszka A. Pilarska ${ }^{2, *}$ \\ ${ }^{1}$ Poznań University of Life Sciences, Institute of Biosystems Engineering, 60637 Poznań, Poland \\ ${ }^{2}$ Poznań University of Life Sciences, Institute of Food Technology of Plant Origin, 60637 Poznań, \\ Poland \\ * Corresponding author: pilarska@up.poznan.pl
}

\begin{abstract}
This paper provides the analysis of results of biogas and methane yield for: maize silage (MS), pig slurry (PS), waste potatoes (WP) and sugar beet pulp (SB). The results show that maize silage is the most energy substrate (among the samples tested), providing a cumulative methane yield from 595 to $631 \mathrm{~m}^{-3} \mathrm{Mg}$ VS (VS - volatile solids). The study was carried out in a laboratory scale using anaerobic batch reactors, at controlled (mesophilic) temperature and $\mathrm{pH}$ conditions. This paper is Part I of a report of an experiment carried out, in the laboratory scale and in the commercial scale (in parallel) The purpose of the experiment was to verify differences in biomethane yields of the same materials in the two scales. Moreover, this paper is an introduction to a presentation of the method to determine the biochemical methane potential correction coefficient (BMPCC), the details of which will be explained in Part II.
\end{abstract}

\section{Introduction}

Intensive development of agriculture contributes to increased volumes of organic waste being generated. Various types of waste matter disposal technology are often based on anaerobic digestion $(\mathrm{AD})$, which is carried out in biogas plants. To improve the biogas plants efficiency, a substrate in the form of organically rich vegetable material is added [1]. For this purpose, specific targeted plantations are established, mainly of maize and grass for silage [2]. The substrates used comprise also animal waste [3] and food-processing waste [4]. The biogas plants generate biogas which is classified as a renewable source of energy because it contains methane. The resulting gas, which is an energy carrier, is quite easily converted to electrical energy and heat.

Therefore, anaerobic digestion is one of the most suitable and advantageous ways to dispose of organic waste, in addition to being a source of biofuel [5]. The process is required to be economically viable and run in a stable manner. The main factors affecting its efficiency, which include the physical and chemical properties of the substrates, $\mathrm{pH}$, and process temperature, are monitored and analyzed [6].

Presented article is Part I of a report of an experiment carried out, in parallel, in the laboratory scale and in the commercial scale. Generally, the purpose of the experiment was to verify differences in biomethane yields of the same materials (maize silage, pig slurry, 
waste potatoes and sugar beet pulp) in the two scales. This paper presents only the laboratory test results as an introduction to a wider discussion of issues connected with the reasons why differences were observed between the laboratory and technical process efficiencies, and with the ability to predict and assess such differences.

\section{Materials and methods}

Laboratory tests were carried out for a period of 6 months both in the laboratory and the commercial scale (using the specific biogas plant selected for the purpose). In this article the laboratory scale methodology was described.

\subsection{Materials}

The green substrates: maize silage (MS) and waste from agro-food processing: pig slurry (PS), waste potatoes (WP), sugar beet pulp (SB) were used in the study. The substrate samples were drawn at monthly intervals, because of changes in their physico-chemical properties potentially taking place on storage.

\subsection{Experimental procedure}

The digestion mixture ratios were established in accordance with the VDI 4630 guideline concerning digestion of organic materials, characterization of substrates, sample taking, collection of essential data, and digestion tests. Based on the said guideline, the present authors attempted to keep the total solids content (TS) of the batch at $10 \%$ less to guarantee adequate mass transfers. The $\mathrm{C} / \mathrm{N}$ ratio of the mixtures was between 10 and 30 and its $\mathrm{pH}$ before digestion was in the range $6.8-7.5$.

Biogas production rates as well as biogas and methane yield analyses were carried out in acordance with the German standard DIN 38 414-S8: Bestimmung des Faulverhaltens (S8) Schlamm und Sedimente (Beuth Verlag GmbH, Berlin 1895). The methane digestion process was carried out in a multichamber biofermenter. Each substrate and the control sample were digested in triplicate. Adequate substrate mixtures were placed in $1.4 \mathrm{~L}$ biofermenters with $1.2 \mathrm{~L}$ of the feed in each. The material was stirred every 24 hours to prevent any uncontrollable decay of the organic matter. The inoculum was added in the absence of oxygen in the digestion chamber, creating the perfect conditions for methane production.

The biofermenters were equipped with a water jacket connected to a heater to control the temperature and carry out the process in a desirable temperature range. The test was carried out in mesophilic temperature conditions (at approx. $39^{\circ} \mathrm{C}$ ). The biogas produced was transported via tube into tanks filled with a neutral liquid [7]. In accordance with the VDI 4630 guideline, the experiment was continued for each substrate until the daily biogas production was below $1 \%$ of its total generated amount.

\subsection{Analytical methods}

\subsubsection{Analysis of substrates}


The substrates were analyzed according to Polish standards or procedures: dry mass (total solids) (drier method PN-EN 12880:2004), organic matter and ash (volatile solids) incineration according to PN-EN 12879:2004 and $\mathrm{pH}$ (potentiometric method PN-EN 12176:2004).

\subsubsection{Analysis of gas samples}

The generated gas volumes were measured every 24 hours. The gas volumes of at least $1 \mathrm{~L}$ were analysed qualitatively, initially once a day, then, as lower volumes were generated, every three days. The concentrations of methane, carbon dioxide, hydrogen sulphide, ammonia, and oxygen were measured with a Geotech GA5000 gas analyser. The gas monitoring system was calibrated once a week by means of calibrating mixtures from Air Products. The calibrating gas mixtures were used at the following concentrations: $65 \%$ $\mathrm{CH}_{4}, 35 \% \mathrm{CO}_{2}$ (in a single mixture) as well as $500 \mathrm{ppm} \mathrm{H}_{2} \mathrm{~S}$ and $100 \mathrm{ppm} \mathrm{NH}_{3}$. The methodology for calculating the cumulative biogas/methane yield is described in the previous articles of present authors [4, 6, 7].

The stability of analytical results obtained in the laboratory was verified using the Shewhart control charts.

\section{Results}

\section{$3.1 \mathrm{pH}$ measurements}

The maize silage which was used for the tests had a $\mathrm{pH}$ ranging from 4.21 (1MS) to 4.39 (3MS). These values were reported in the literature [8]. The pig slurry in the tests had a rather narrow $\mathrm{pH}$ range between 7.22 (5PS) and 7.56 (1PS). These values are comparable to those reported in the literature [9]. Hydrogen ion concentration in the waste potato pulp was in the range from 7.44 (3WP) to 7.78 (4WP). This is lower than the value 8.07 , reported in the literature for potatoes [10]. The lower $\mathrm{pH}$ value is attributed mainly to the fact that the waste material had rotten a bit before use. The $\mathrm{pH}$ of the sugar beet pulp was from 5.01 (1SB) to 5.18 (3SB), which is in conformity with the values reported by other authors [11].

\subsection{The values of total solids and volatile solids in the substrates}

The value of total solids for the maize silage which was used in the test plants ranged from $32.21 \%$ (2MS) to $31.06 \%$ (6MS) (see Fig. 1). These values were conformable with the recommendations by Kukier et al. (2014) [8]. The pig slurry had a total solids content in the range from $4.32 \%$ (2PS) to $5.06 \%$ (6PS), which is in conformity with the literature reports [12]. In the waste potato pulp, the total solids content was in the range from $21.33 \%$ (2WP) to $21.86 \%$ (6WP). This range is comparable to the values reported in the literature [10]. For the sugar beet pulp, the values of total solids ranged from $23.33 \%$ (6SB) to $23.88 \%$ (1SB), which is in conformity with the literature data [11].

The substrates, selected for the experiment, being rich in volatile solids are a valuable feedstock for biogas plants. Their organic content is divided into three essential groups: carbohydrates, proteins and fats. The test materials were composed mainly of sugars and proteins. Volatile solids (organic content) for maize silage ranged from $93.88 \%$ (6MS) to 95.15\% (1MS) (see Fig. 1), which is comparable to the literature data [13]. The pig slurry had an organic content from $76.88 \%$ (2PS) to $81.32 \%$ (4PS). 


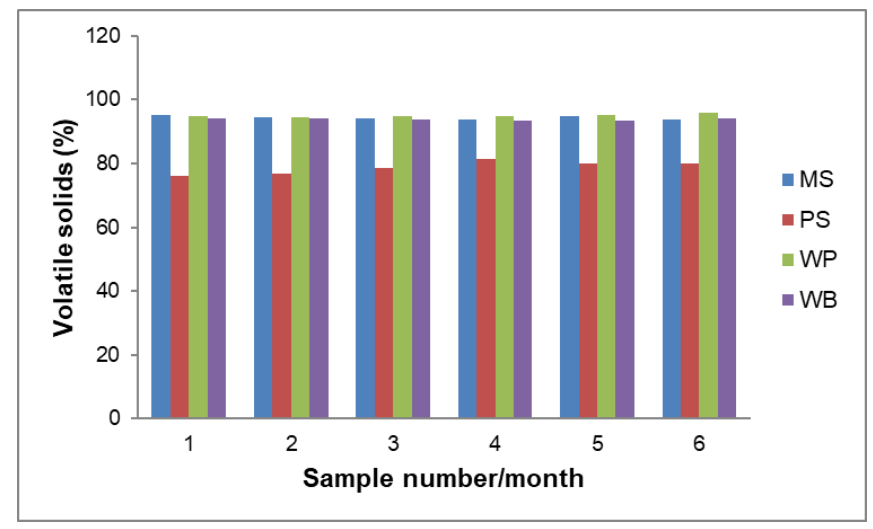

Fig. 1. Volatile solids of the tested samples: MS, PS, WP and WB

These values were similar to those shown in the literature [14]. The quality of the pig slurry depends on the breed of animals generating the material, their feed, and degree of dilution with water [15]. For the waste potato pulp, the value of volatile solids was in the range from $94.61 \%$ (2WP) to $95.92 \%$ (6WP). The sugar beet pulp material is advantageous to the efficiency of anaerobic digestion per unit of digester volume because of its carbohydrate content. In the analyzed material, the volatile solids was between $93.32 \%$ (4SB) and $94.16 \%(1 \mathrm{SB})$.

\subsection{Biogas production in terms of fresh matter (average values)}

The biogas yield of maize silage was $183 \pm 5 \mathrm{~m}^{3} \mathrm{Mg}^{-1} \mathrm{FM}$ (FM - fresh matter). The obtained biogas volumes are comparable to the literature data [16]. The biogas yield obtained from the pig slurry was $20.1 \pm 3 \mathrm{~m}^{3} \mathrm{Mg}^{-1} \mathrm{FM}$. The biogas volume per ton of fresh matter was low, which results from the low content of total solids in the pig slurry. The biogas volume obtained from the waste potatoes was $69.2 \pm 2.1 \mathrm{~m}^{3} \mathrm{Mg}^{-1} \mathrm{FM}$. The volume obtained from fresh matter of sugar beet pulp was $96.4 \pm 3.2 \mathrm{~m}^{3} \mathrm{Mg}^{-1} \mathrm{FM}$. These values are similar to those reported in the literature [17].

\subsection{Biogas production in terms of volatile solids}

The biogas yield of maize silage in terms of volatile solids was from 595 (4MS) to $631 \mathrm{~m}^{3}$ $\mathrm{Mg}^{-1} \mathrm{VS}$ (6MS) (see Fig. 2). Between $450 \mathrm{~m}^{3} \mathrm{Mg}^{-1} \mathrm{VS}$ (6PS) and $582 \mathrm{~m}^{3} \mathrm{Mg}^{-1} \mathrm{VS}$ (3PS) was obtained from the pig slurry. The biogas volume obtained from the waste potatoes was from $329 \mathrm{~m}^{3} \mathrm{Mg}^{-1} \mathrm{VS}$ (3WP) to $342 \mathrm{~m}^{3} \mathrm{Mg}^{-1} \mathrm{VS}$ (2WP), which is in conformity with the literature data [11]. The biogas volume of the sugar beet pulp ranged from $425 \mathrm{~m}^{3} \mathrm{Mg}^{-1} \mathrm{VS}$ (5SB) to $440 \mathrm{~m}^{3} \mathrm{Mg}^{-1} \mathrm{VS}$ (1SB and $2 \mathrm{SB}$ ) $\mathrm{m}^{3} \mathrm{Mg}^{-1} \mathrm{VS}$. These efficiencies are much lower than the results presented by reporting, for the sugar beet pulp, a biochemical methane potential of $504 \mathrm{~m}^{3} \mathrm{Mg}^{-1} \mathrm{VS}$ [18]. While a higher value, $540 \mathrm{~m}^{3} \mathrm{Mg}^{-1} \mathrm{VS}$, was reported by Ogrodowczyk et al. (2016) [19]. 


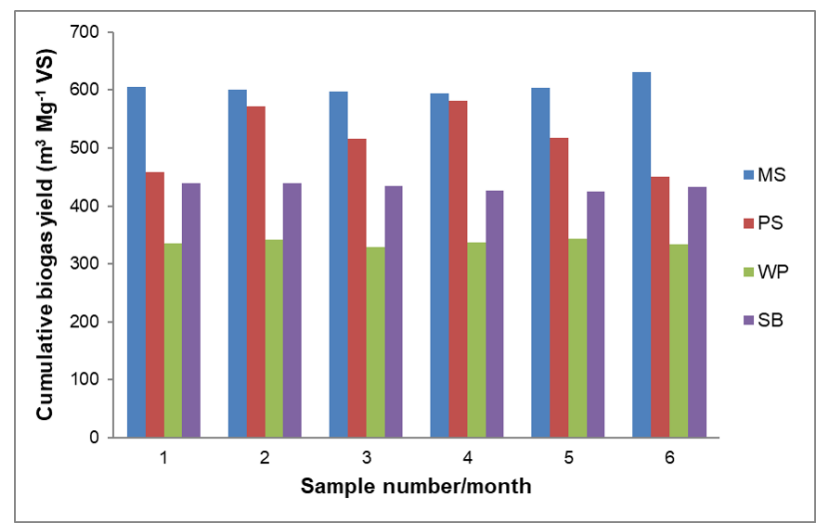

Fig. 2. Cumulative biogas yield from Mg of volatile solids for: MS, PS, WP and SB.

\subsection{Methane volume concentration in biogas}

Another analysis which was required in this research work was to measure the content of methane in the biogas (Fig. 3). The methane concentration by volume of the biogas obtained from the maize silage was from $50.4 \%$ (3MS) to $52.3 \%$ (2MS). The methane content of the biogas obtained from the pig slurry ranged from 50.8 (2PS) to 52.6\% (5PS). Methane content of the biogas obtained from the waste potatoes was from $50.7 \%$ (2WP) to $52.2 \%$ (5WP). On the other hand, the values of methane content per unit of biogas volume obtained from the sugar beet pulp was from $50.2 \%$ (1SB) to $52.8 \%$ (4SB). Generally, the obtained concentrations are equivalent to the available data [20].

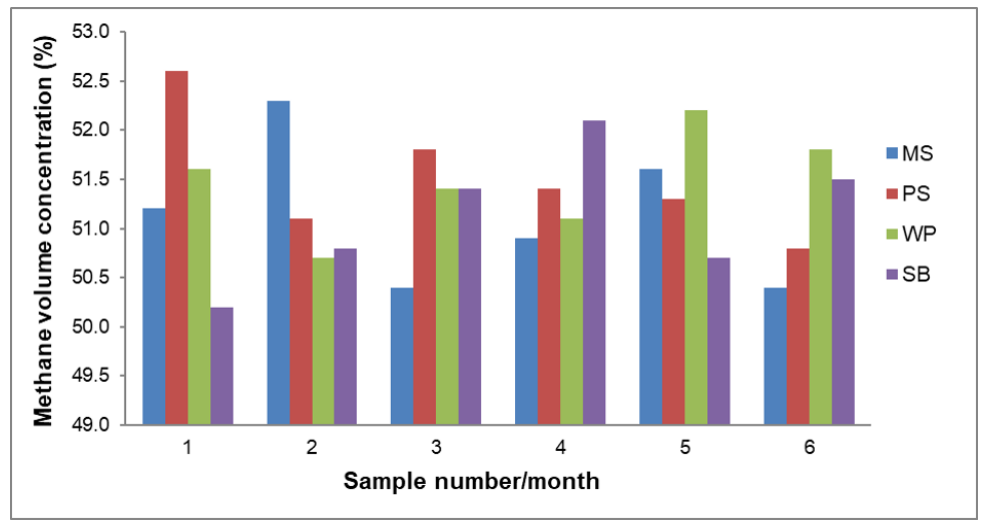

Fig. 3. Methane volume concentration in biogas for tested samples.

Based on the laboratory results, a substrate feeding cycle was developed. The substrate feeding volume was supposed to be suitable for a $1 \mathrm{MW}_{\mathrm{el}}$ biogas plant.

\section{Conclusions}

The largest amount of biogas was obtained from maize silage (from 595 to $631 \mathrm{~m}^{3} \mathrm{Mg}^{-1}$ VS) and the lowest from waste potatoes (from 329 to $342 \mathrm{~m}^{3} \mathrm{Mg}^{-1} \mathrm{VS}$ ). The efficiency of anaerobic digestion is related to the physicochemical and chemical properties of the materials tested. The results obtained in presented study are comparable with data in 
literature. In the second part of this work, the yields from the laboratory scale with industrial scale results will be compared.

Acknowledgements: This research was funded by the company Biolab-Energy A\&P, Poznan, Poland.

\section{References}

1. B. Stürmer, Biomass Bioenerg. 98, 228 (2017)

2. P.C.R. Carmona, K. Witaszek, D. Janczak, W. Czekała, A. Lewicki, J. Dach, K. Pilarski, R. Mazur, Arch. Waste Manage. Environ. Prot. 16, 21 (2014)

3. F.P.C. Müller, G.C. Maack, W. Buescher, Energies, 10, 325 (2017)

4. A.A. Pilarska, K. Pilarski, A. Wolna-Maruwka, P. Boniecki, M. Zaborowicz, Molecules 24, 37 (2019)

5. K. Hagos, J. Zong, D. Li, C. Liu, X. Lu, Renew. Sust. Energy Rev. 76, 1485 (2017)

6. A.A. Pilarska, A. Wolna-Maruwka, K. Pilarski, Energies 11, 3246 (2018)

7. A.A. Pilarska, K. Pilarski, A. Wolna-Maruwka, Environ. Eng. Sci. 36, 478 (2019)

8. E. Kukier, K. Kwiatek, T. Grenda, M. Goldsztejn, Życie Weterynaryjne, 89, 1031 (2014)

9. M. Marszałek, Z. Kowalski, Makara A., Tech. Trans. Chem. 111, 81 (2014)

10. S. Bartnikowska, W. Czekała, A. Lewicki, A. Olszewska, A. Smurzyńska, M. Brzoski, Rocz. Ekon. Rol. Rozw. Obsz. Wiej. 104, 66 (2017)

11. B. Połeć, A. Baryga, T. Szymański, M. Kowalska, Post. Nauki Technol. Przem. Rol. Spoż. 68, 46 (2013)

12. W. Bednarek, P. Tkaczyk, S. Dresler, Acta Agrophys. 16, 5 (2010)

13. C. Herrmann, C. Idler, M. Heiermann, Bioresour. Technol. 197, 393 (2015)

14. T. Banaszkiewicz, J. Wysmyk, 2015. Europ. Region. 23, 21 (2015)

15. Z. Kowalski, A. Makara, K. Fijorek, Acta Biochim. Pol. 60, 845 (2013)

16. K. Pilarski, A.A. Pilarska, K. Witaszek, Z. Dworecki, T. Żelaziński, A. Ekielski, A. Makowska, J. Michniewicz, J. Ecol. Eng. 17, 264 (2016)

17. S. Suhartini, S. Heaven, C.J. Banks, IOP Conf. Series: Earth Environ. Sci. 131, 1 (2018)

18. I. Miroshnichenko, J. Lindner, A. Lemmer, H. Oechsner, I. Vasilenko, Landtechnik 71, 175 (2016)

19. D. Ogrodowczyk. T.P., Olejnik, M. Kaźmierczak, S. Brzeziński, A. Baryga, Biotechnol. Food Sci. 80, 129 (2016)

20. J. Pessuto, B.S. Scopel, D. Perondi, M. Godinho, A. Dettmer, Process Saf. Environ. Prot. 104, 233 (2016) 